\title{
Application of Bauxite Waste from Amazon Region in the Heavy Clay Industry
}

\author{
Edemarino Araujo Hildebrando**, José Antônio da Silva Souza ${ }^{\mathrm{b}}$, \\ Rômulo Simões Angélica ${ }^{c}$, Roberto de Freitas Neves ${ }^{b}$
}

\author{
${ }^{a}$ Faculty of Materials Engineering, Federal University of Pará - UFPA, \\ Folha 17, Quadra 04, Lote Especial, CEP 68505-080, Marabá, PA, Brazil \\ ${ }^{\mathrm{b}}$ Faculty of Chemical Engineering, Federal University of Pará - UFPA, \\ Av. Augusto Corrêa s/n, CEP 66075-110, Belém, PA, Brazil \\ ${ }^{c}$ Faculty of Geology, Federal University of Pará - UFPA, \\ Av. Augusto Corrêa s/n, CEP 66075-110, Belém, PA, Brazil
}

Received: September 26, 2012; Revised: July 19, 2013

\begin{abstract}
In this work, a method was developed for the application of red mud, an alkaline leaching waste, from a bauxite processing plant located in northern Brazil (Amazon region) as starting material for heavy clay products. Samples were prepared by pressing blends of red mud and clay, which were then fired at temperatures from $900{ }^{\circ} \mathrm{C}$ to $1190^{\circ} \mathrm{C}$. Characterization was carried out by chemical analysis, differential thermal analysis (DTA) and X-ray diffraction (XRD), and the following ceramic properties were evaluated: water absorption, linear shrinkage and flexural strength. In order to evaluate the $\mathrm{Na}^{+}$ stability in the dense ceramic, leaching tests were also carried out on the specimens after sintering process. Results indicated that samples with 50 and $70 \mathrm{wt} \%$ of red mud are proper for being used in the production of ceramic bodies, due to its excellent properties, mainly high mechanical resistance and low water absorption, showing thus, an option to minimizing the environmental impacts caused by the aluminum industry.
\end{abstract}

Keywords: traditional ceramics, red mud, bauxite waste

\section{Introduction}

Mining wastes accumulate at higher rates as a consequence of the increasing consumption of metals in the world and the growing exploitation of mineral deposits. Their disposal raises several environmental situations. Special problems occur related to residues which contain heavy metal ions, surfactants, acids, etc., which may affect surface and underground water quality ${ }^{1,2}$. One of these wastes, known as red mud, contains a significant amount of oxides, such as ferric oxide, calcium oxide, titanium and sodium oxide, among others, that are the main constituents, besides trace elements like Ga, V, Sr, Zr, Y, Th, U, etc. Most of these compounds are originally present in the bauxites and others are added during Bayer process for the alumina production (e.g., $\mathrm{NaO})^{[3]}$. The presence of such alkaline oxides in the red mud lead to a corrosive action on metals, siliceous materials and living beings ${ }^{4}$.

Solving or minimize these problems involves mainly an improvement and a better optimization of production in order to generate the least amount of waste. Among the several industrial segments, the alumina industry faces a world-class problem namely the increasing disposal of solid wastes that is very common in the Bayer processing ${ }^{5,6}$. Generally, 0.8-1.5 tons of red mud is generated from each ton of alumina produced. With the quick development of alumina industry all over the world, the disposal of red mud has caused serious environmental problems mainly due to

*e-mail: edemarino@ufpa.br its large quantities and strong alkalinity $(\mathrm{pH} 10.0-12.5)^{[7]}$. As same bauxites contain radioactive elements, the red mud, has characteristic radioactivity, which can accumulate in the dam construction and storage yards endanger human health ${ }^{4}$.

Tsakiridis et al. ${ }^{8}$ estimated that over 66 million tons of red mud is impounded annually in the world (around 85 alumina plants worldwide). The disposal of such a huge amount of alkaline waste is very expensive (up to $1-2 \%$ of the alumina price), and requires large areas of occupation (approximately $1 \mathrm{~km}^{2}$ per 5 years for a 1 Mtpy alumina plant). Alunorte company, located at Pará State in the Brazilian Amazonia, produces 4.40 million tons/year of alumina, with an expected 6.26 million tons/year capacity ${ }^{9}$ which will produce an even larger volume of red mud as waste.

As a corrosively hazardous material, the comprehensive utilization of red mud has attracted more and more interest from the scientific community. Thus, a number of efforts have been made in order to find possible applications for this material, as for example, as catalysts materials ${ }^{10}$, fillers in $\mathrm{PVC}^{11}$, pigment ${ }^{12}$, for the recovery of some valuable elements ${ }^{13}$, cements manufacturing $8,14-16$, water treatment ${ }^{17,18}$, among others. Unfortunately, several reuse techniques consume relatively small amounts of waste compared to the huge amount produced. Therefore, one of the most appealing application should be the reuse of red mud as a starting material for the production of construction and 
building materials ${ }^{4,19-22}$. Sglavo et al. ${ }^{20}$ investigated the use of red mud as a raw component in clay mixtures for ceramic bodies production and the influence in the amount of red mud (0-20 wt \%) and sintering temperature $\left(950-1050{ }^{\circ} \mathrm{C}\right)$ on the final properties of the produced material was analyzed. Recently, Qin and $\mathrm{Wu}^{4}$, prepared a novel ceramic material at $1020-1050{ }^{\circ} \mathrm{C}$ using $30 \mathrm{wt} \%$ of red mud. The authors investigated the radiation level, and concluded that the ceramic materials produced using red mud are not harmful to humans beings or to the environment.

Considering all the concerns described above, the main purpose of the present work was to develop a method to verify how the bauxite waste (red mud) from Brazilian Amazon region could be used as a raw material in the ceramic industry, using it not only as an additive, i.e., in small quantities, but in high concentrations. Thus, studies were performed about the ceramic properties of the sintered material and the data were compared with the values found in scientific literature directed to red ceramics. Leaching tests on the final products were also carried.

\section{Material and Methods}

\subsection{Raw materials}

The red mud studied in this work was supplied by Alunorte company (Amazon region, Para State, Brazil. The sample was collected directly from the tailings basin and its moisture content is around 9\%. The clay used for the blends occurs as a compact brown material with red mottling related to tertiary geological formations. Samples were collected from outcrops located nearby the Alunorte plant.

The raw materials were characterized by X-ray diffraction (XRD), differential thermal analysis (DTA) and chemical analysis. The mineralogical composition of the bulk materials (randomly oriented samples) was carried out by Powder X-ray diffractometry (XRD), using a Panalytical X'Pert PRO MPD (PW3040/60) diffractometer with a ceramic X-ray tube $\left(\lambda \mathrm{CuK} \alpha_{1}=0.1540598 \mathrm{~nm}\right), \mathrm{K} \beta$ Ni filter and a $X^{\prime}$ celerator PSD (Position-Sensitive Detector). The following analysis conditions were used: scan range from 5 to $70^{\circ} 2 \theta, 40 \mathrm{kV}$ and $30 \mathrm{~mA}, 0.02^{\circ}$ step size and $10 \mathrm{~s}$ time/step; divergent slit of $1 / 4^{\circ}$ and anti scattering of $1 / 2^{\circ}$; mask of $10 \mathrm{~mm}$; sample movement set to spinning with a rotation time of $1.0 \mathrm{~s}$. Differential thermal analysis (DTA) of $\approx 17 \mathrm{mg}$ of sample were carried out in a Thermal Science Thermoanalyzer model PL-STA. The experiments used alumina crucibles and $\mathrm{N}_{2}$ atmosphere with a flow rate of $50 \mathrm{cc} \mathrm{min}{ }^{-1}$ at a heating time of $20^{\circ} \mathrm{C} \mathrm{min}^{-1}$ to $1100{ }^{\circ} \mathrm{C}$. Total chemical analysis (major oxides and trace elements) were obtained by using a combination of methods, including wet analytical methods and Atomic Absorption Spectrometry.

\subsection{Sample preparation and sintering methods}

Samples of clay and red mud were dried at $110{ }^{\circ} \mathrm{C}$ until constant weight, mixed and homogenized with water, using the following proportions: $70 \mathrm{wt} \% \mathrm{red}$ mud / $30 \mathrm{wt} \%$ clay and $50 \mathrm{wt} \%$ red mud/50 wt $\%$ clay; the percentages of red mud were established from Hildebrando et al. ${ }^{23}$. The mixtures were then dried at $110^{\circ} \mathrm{C} / 24 \mathrm{~h}$, grinded and screened through a 80 Mesh Tyler sieve. Batches of eight green specimens $(10.0 \mathrm{~cm} \times 5.0 \mathrm{~cm} \times 1.0 \mathrm{~cm}$ bodies $)$ were pressed (axial compressive strength) at $20 \mathrm{MPa}$.

The ceramic bodies were named as follow: RM-50 (50\% red mud and 50\% clay) and RM-70 (70\% red mud and $30 \%$ clay). During firing in a muffle electrical furnace, the heating and cooling rates were kept at $10^{\circ} \mathrm{C} / \mathrm{min}$ and the specimens were maintained at the maximum temperature $\left(900{ }^{\circ} \mathrm{C}, 950{ }^{\circ} \mathrm{C}, 1000{ }^{\circ} \mathrm{C}\right.$, and $1190{ }^{\circ} \mathrm{C}$ ) for 3 hours. Such sintering temperatures were used according to Monteiro and Vieira ${ }^{24}$, and several others references from the scientific and technological literature.

\subsection{Mechanical properties}

The samples were submitted to the following tests: water absorption (WA) determined from the weight differences between the as-sintered and water soaked samples (immersed in boiling water for 2 hours), linear shrinkage (LS) evaluated from the variation of the length of the rectangular pieces, and flexural strength (FS). Flexural strength was obtained by the three points bend test performed in a universal test machine ${ }^{25,26}$.

\subsection{Sodium contents in the samples after sintering}

Samples were submitted to leaching tests, according to the technical standard NBR $10005^{[27]}$, in order to detect possible polluting factors from the soluble sodium in the ceramic bodies.

\section{Results and Discussion}

The chemical composition of the raw materials dried at $110{ }^{\circ} \mathrm{C}$ is shown in Table 1 .

Red mud possesses high amount of fusing material, as expected, such as sodium and iron which can reduce the sintering temperature for adequately formulated mixtures. The amount of silica $\left(\mathrm{SiO}_{2}\right)$ present in the red mud is low $(19.9 \%)$ so it cannot be used alone as it is not enough to form the glass that would give mechanical resistance to the sintered material.

The clay is mainly constituted by $\mathrm{SiO}_{2}(51.8 \%), \mathrm{Al}_{2} \mathrm{O}_{3}$ $(24.5 \%)$ and $\mathrm{Fe}_{2} \mathrm{O}_{3}(10.9 \%)$ and a low amount of fusing compounds $\left(\mathrm{Na}_{2} \mathrm{O}+\mathrm{K}_{2} \mathrm{O}<0.35 \%\right)$. These features render

Table 1. Chemical composition (wt \%) of the raw materials.

\begin{tabular}{lccccccccc}
\hline & $\mathbf{F e}_{2} \mathbf{O}_{\mathbf{3}}$ & $\mathbf{T i O}_{2}$ & $\mathbf{C a O}$ & $\mathbf{S i O}_{2}$ & $\mathbf{A l}_{2} \mathbf{O}_{3}$ & $\mathbf{N a}_{2} \mathbf{O}$ & $\mathbf{K}_{2} \mathbf{O}$ & $\mathbf{M g O}$ & $\mathbf{L O} *$ \\
\hline Red mud & 38.0 & 3.83 & 0.87 & 19.9 & 19.0 & 8.58 & 0.12 & 0.04 & 10.1 \\
Clay & 10.9 & 1.72 & 0.02 & 51.8 & 24.5 & $<0.06$ & 0.27 & 0.09 & 10.3 \\
\hline
\end{tabular}

*LOI (loss on ignition). 
the clay economically unfit for use in red ceramic products, due to its high sintering temperatures.

The differential thermal analysis (DTA) for the clay, shown in Figure 1, portrays two endothermic peaks, one at $130{ }^{\circ} \mathrm{C}$ due to water loss and another at $550{ }^{\circ} \mathrm{C}$ due to dehydroxilation that is characteristic to kaolinite. Right after these peaks a low intensity exothermic peak is observed near the $970{ }^{\circ} \mathrm{C}$, characteristic of the formation of the siliconaluminum spinel ${ }^{28}$.

The DTA for the red mud, shown in Figure 1, portrays a wide endothermic band in the range $100{ }^{\circ} \mathrm{C}-280{ }^{\circ} \mathrm{C}$ and can be discussed in two parts. The first in the range $100{ }^{\circ} \mathrm{C}-150{ }^{\circ} \mathrm{C}$ is related with the evaporation of physical water content of the red mud while the second part $150{ }^{\circ} \mathrm{C}-280{ }^{\circ} \mathrm{C}$ can be explained by the loss of zeolitic water and by the dehydrolixation of ferrous compounds; these bands are in good agreement with the reported by Castaldi et al. ${ }^{29}$. The endothermic peak at $310^{\circ} \mathrm{C}$ corresponds to the temperature of decomposition of gibbsite ${ }^{29}$, and that acoording to Atasoy ${ }^{30}$ gibbsite partially dehydroxylates to boehmite and the remained part of the gibbsite goes to a transition of alumina at $314{ }^{\circ} \mathrm{C}$.

Figure 2 presents the X-ray patterns of red mud and clay dried at $110{ }^{\circ} \mathrm{C}$. In general, the minerals that are present

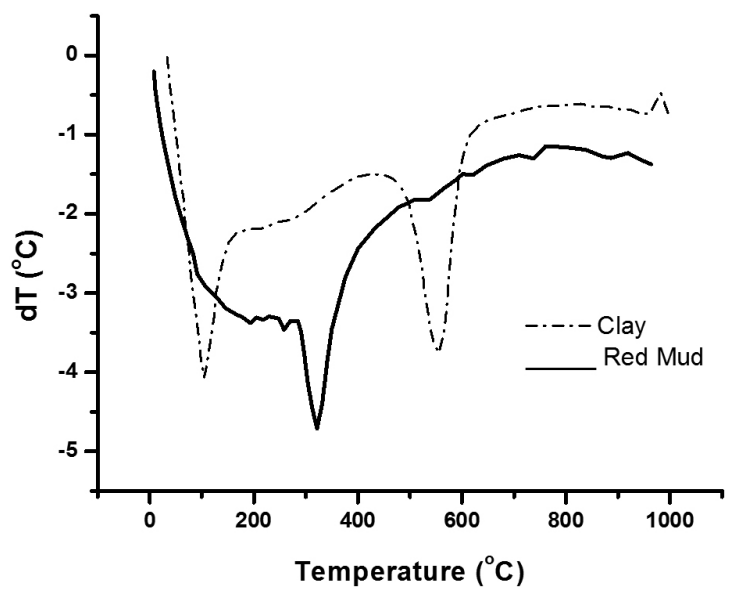

Figure 1. Differential thermal analysis (DTA) of red mud and clay.

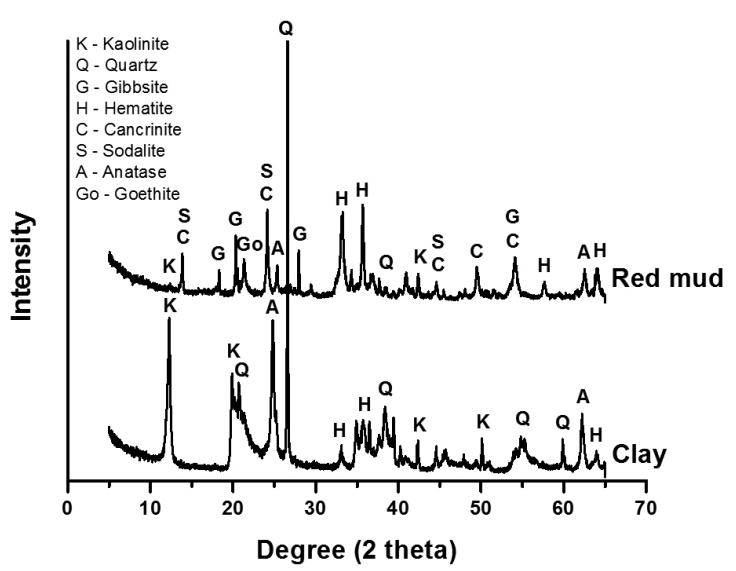

Figure 2. X-ray patterns of red mud and clay. in the sample of red mud, can be identify and classify in two categories. In the first, phases from bauxite such as gibbsite, hematite, goethite, anatase and quartz; this results are similar to those reported by Rivas Mercury et al. ${ }^{31}$. The second category, phases formed during Bayer process such as sodalite and cancrinite ${ }^{29}$. In turn, the clay is constituted mostly by the clay mineral kaolinite and other mineral phases such as hematite, quartz and anatase.

Figure 3 and 4 displays the results of ceramic properties conducted on the bodies after sintering process. Figure 3 shows the curves for water absorption and linear shrinkage. This type of curves is also known as gresification diagram, which is associated with the efficiency of the sintering process. The sintering of a material usually causes many changes in its properties. In ceramics, the changes generally are accompanied by shrinkage as the temperature is increased. During this process, the particles are bound together, reducing porosity and making difficult the water absorption by the material ${ }^{23}$. In general, the curves in Figure 3 show a decrease in the water absorption values as the linear shrinkage is increased, while the sintering is carried out. According to Brazilian norms ${ }^{32,33}$ the maximum water absorption for bricks and roofing tiles are $22 \%$

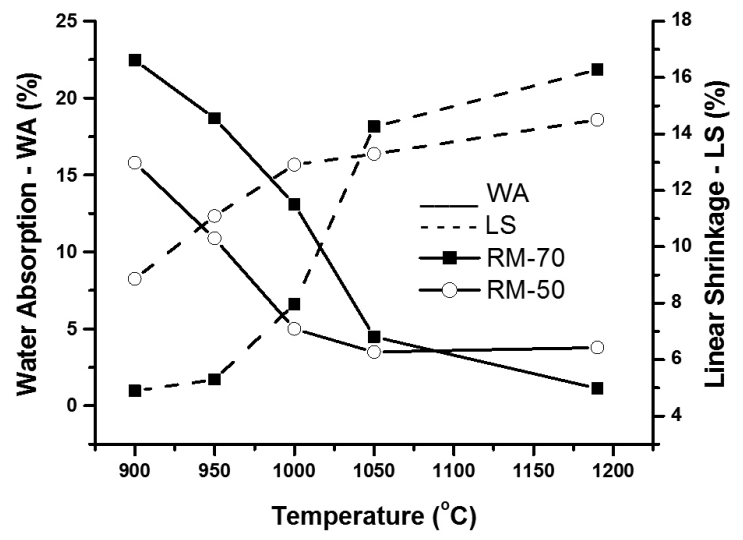

Figure 3. Gresification diagram of samples RM-70 and RM-50.

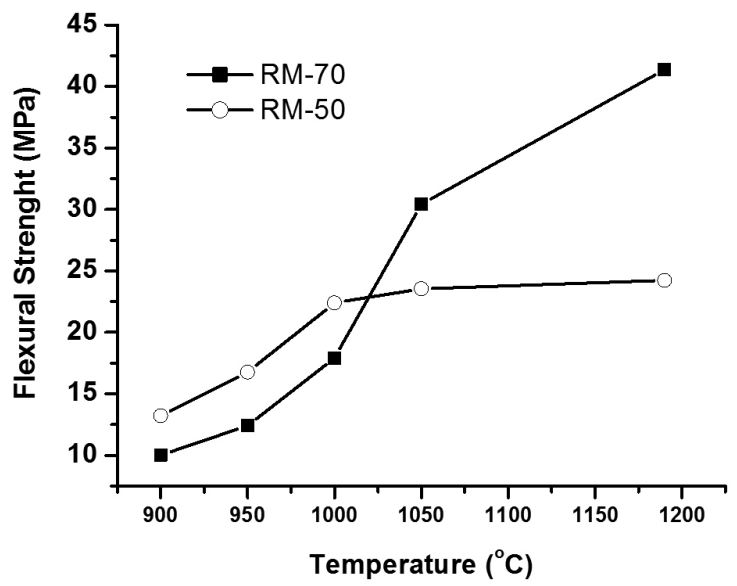

Figure 4. Flexural strength of samples RM-70 and RM-50. 


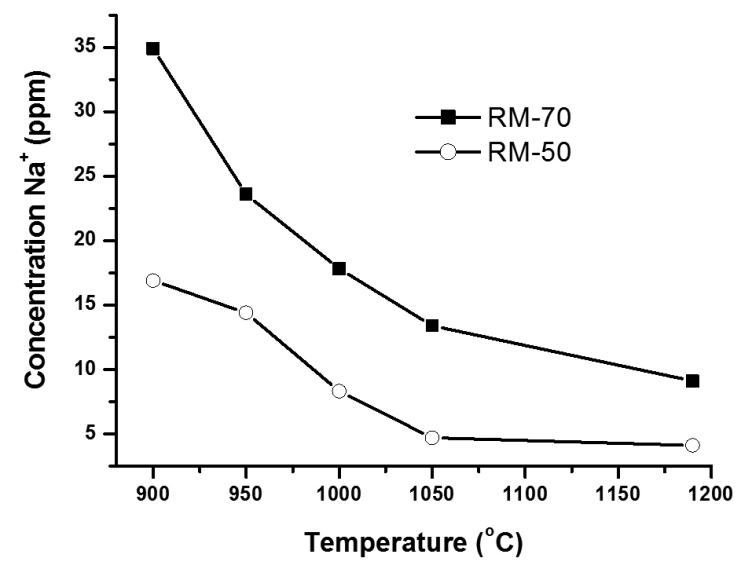

Figure 5. Leaching tests of ceramic bodies (RM-70 and RM-50).

and 20\%, respectively. It is observed in Figure 3 that the specification for bricks roofing tiles was achieved in the studied temperature range $\left(900-1150^{\circ} \mathrm{C}\right)$ for sample RM-50 while the sample RM-70 attained only above $950{ }^{\circ} \mathrm{C}$

One of the most significant modifications of the ceramic products after sintering is the improvement in its mechanical resistance ${ }^{34}$. Samples RM-70 and RM-50 showed an increasing trend in such values, and this is substantiated by the presence of alkaline fluxes in the formulations from red mud, which cause densification by liquid phase sintering with the creating more glass phases to form glass network structures. It is important mentioning that the values measured ( $>10 \mathrm{MPa}$ ) were above the limits recommended for red ceramics by technical standards $s^{32,33}$ and were better that found in previous works ${ }^{20}$. Figure 4 evidenced the variation with temperature of the flexural strength for the samples studied.

As can be seen in Figure 5, the concentration of sodium decreased at higher sintering temperatures. This is due to

\section{References}

1. Zhang Y, Qu Y and Wu S. Engineering geological properties and comprehensive utilization of the solid waste (red mud) in aluminium industry. Environmental Geology. 2001; 41:249-256. http://dx.doi.org/10.1007/s002540100399

2. Brunori C, Cremisini C, Massanisso P, Pinto V and Torricelli R. Reuse of a treated red mud bauxite waste: studies on environmental compatibility. Journal of Hazardous Materials. 2005; 117:55-63. PMid:15621353. http://dx.doi. org/10.1016/j.jhazmat.2004.09.010

3. Yang J, Zhang D, Hou J, He B and Xiao B. Preparation of glassceramics from red mud in the aluminium industries. Ceramics International. 2008; 34:125-130. http://dx.doi.org/10.1016/j. ceramint.2006.08.013

4. Qin S and Wu B. Reducing the radiation dose of red mud to environmentally acceptable levels as an example of novel ceramic materials. Green Chemistry. 2011; 13:2423-2427. http://dx.doi.org/10.1039/c1gc15452d

5. Liu W, Yang J and Xiao B. Review on treatment and utilization of bauxite residues in China. International Journal of Mineral reactions mainly between sodium present in the red mud and silicates in the clay, when both raw materials are blended. This strongly contributes for the formation of more vitreous phase in the sintered material.

For both samples (RM-70 and RM-50) the concentrations of sodium were into a tolerable range, given the limit of 200 ppm adopted by the Ministry of Health - Brazilian Standard for Fresh Water. This reveals that products fabricated from the mixtures of red mud and clay in both compositions would not be aggressive to the environment and would classify as Waste Class III - inert according to standards NBR $10004^{35}$.

\section{Conclusions}

The application of red mud in mixtures with clay offers an interesting alternative for the fabrication of products of heavy clay industry, especially because of the low cost of raw materials, in particular the red mud which is produced in large quantities as bauxite processing waste. Samples with 50 and $70 \mathrm{wt} \%$ of red mud demonstrated all the possibilities of being used in the production of bricks and compact blocks given their excellent qualities mainly high mechanical resistance and low water absorption. The sintering process that took place into the mixture of clay and red mud was able to fix the soluble sodium which was largely present in the mixture. The leaching tests showed that the increasing in sintering temperature led to a decreasing in concentration of sodium residuals, owing to reactions that occurred during sintering. Further studies should be performed in order to check the occurrence of efflorescence of soluble salts and leaching from other metals present in the red mud should be evaluated.

\section{Acknowledgements}

The authors would like to thank the Brazilian agency CAPES for financial support.

Processing. 2009; 93:220-231. http://dx.doi.org/10.1016/j. minpro.2009.08.005

6. Venancio LCA, Souza JAS, Macêdo EN, Quaresma JNN and Paiva AEM. Residues Recycling: Reducing Costs and Helping the Environment. Journal of the Minerals, Metals \& Materials Society. 2010; 62:41-45. http://dx.doi.org/10.1007/ s11837-010-0135-2

7. Zhang N, Liu X, Sun H and Li L. Evaluation of blends bauxitecalcination-method red mud with other industrial wastes as a cementitious material: Properties and hydration characteristics. Journal of Hazardous Materials. 2011; 185:329-335. PMid:20932639. http://dx.doi.org/10.1016/j. jhazmat.2010.09.038

8. Tsakiridis PE, Agatzini-Leonardou S and Oustadakis P. Red mud addition in the raw meal for the production of Portland cement clinker. Journal of Hazardous Materials B. 2004; 116:103-110. PMid:15561368. http://dx.doi. org/10.1016/j.jhazmat.2004.08.002

9. Alumina do Norte do Brasil S/A - ALUNORTE. Available from: <http://www.alunorte.net>. Access in: 17/01/2010. 
10. Sushil S and Batra VS. Catalytic applications of red mud, an aluminium industry waste: A review. Applied Catalysis B:Environmental. 2008; 81:64-77. http://dx.doi.org/10.1016/j. apcatb.2007.12.002

11. Karayildirim T, Yanik J, Yuksel M, Saglam M, Vasile C and Bockhorn $\mathrm{H}$. The effect of some fillers on PVC degradation. Journal of Analytical and Applied Pyrolysis. 2006; 75:112-119. http://dx.doi.org/10.1016/j.jaap.2005.04.012

12. Pera J, Boumaza R and Ambroise J. Development of a pozzolanic pigment from red mud. Cement and Concrete Research. 1997; 27(10):1513-1522. http://dx.doi.org/10.1016/ S0008-8846(97)00162-2

13. Ochsenkiihn-Petropulu M, Lyberopulu Th, Ochsenkiihn KM and Parissakis G. Recovery of lanthanides and yttrium from red mud by selective leaching. Analytica Chimica Acta. 1996; 319:249-254. http://dx.doi.org/10.1016/00032670(95)00486-6

14. Maneesh S, Upadhayay SN and Prasad PM. Preparation of special cements from red mud. Waste Management. 1996; 8:665-670.

15. Pan Z, Li D, Yu J and Yang N. Properties and microstructure of the hardened alkali-activated red mud-slag cementitious material. Cement and Concrete Research. 2003; 33:1437-1441. http://dx.doi.org/10.1016/S0008-8846(03)00093-0

16. Ribeiro DV, Labrincha JA and Morelli MR. Potential use of natural red mud as pozzolan for Portland cement. Materials Research. 2011; 14(1):60-66. http://dx.doi.org/10.1590/S151614392011005000001

17. Gupta VK, Gupta M and Sharma S. Process development for the removal of lead and chromium from aqueous using red mud-an aluminium industry waste. Water Research. 2001; 35(5):1125-1134. http://dx.doi.org/10.1016/ S0043-1354(00)00389-4

18. Altundogan HS, Altundogan S, Tümen F and Bildik M. Arsenic adsorption from aqueous solutions by activated red mud. Waste Management. 2002; 22:357-363. http://dx.doi.org/10.1016/ S0956-053X(01)00041-1

19. Yalçin $\mathrm{N}$ and Sevinç V. Utilization of bauxite waste in ceramic glazes. Ceramics International. 2000; 26:485-493. http:// dx.doi.org/10.1016/S0272-8842(99)00083-8

20. Sglavo VM, Maurina S, Conci A, Salviati A, Carturan G and Cocco G. Bauxite "red mud" in the ceramic industry. Part 2: production of clay-based ceramics. Journal of the European Ceramic Society. 2000; 20:245-252. http://dx.doi.org/10.1016/ S0955-2219(99)00156-9

21. Mymrin VA and Vázquez-Vaamonde AJ. Red mud of aluminium production waste as basic component of new construction materials. Waste Management \& Research. 2001; 19:465-469. http://dx.doi.org/10.1177/0734242X0101900512
22. Yang $\mathbf{J}$ and Xiao B. Development of unsintered construction materials from red mud wastes produced in the sintering alumina process. Construction and Building Materials. 2008; 22:22992307. http://dx.doi.org/10.1016/j.conbuildmat.2007.10.005

23. Hildebrando EA, Souza JAS and Neves RF. Influence of the type of clay over the mechanical and physical properties of ceramic proofs with red mud from the Bayer process. In: Proceedings of the 17th Brazilian Congress on Materials Science and Engineering; 2006; Fox do Iguaçu. Fox do Iguaçu; 2006. p. 1574-1583.

24. Monteiro SN and Vieira CMF. Solid state sintering of red ceramics at lower temperatures. Ceramics International. 2004; 30:381-387. http://dx.doi.org/10.1016/S0272-8842(03)00120-2

25. American Society for Testing and Materials - ASTM. ASTM C373: Water Absorption, Bulk Density, Apparent Porosity, and Apparent Specific Gravity of Fired Whiteware Products. Philadelphia: ASTM; 1972.

26. American Society for Testing and Materials - ASTM. ASTM C674: Flexural properties of ceramic whiteware materials. Philadelphia: ASTM; 1977.

27. Associação Brasileira de Normas Técnicas - ABNT. NBR 10005: Lixiviação de resíduos. Rio de Janeiro: ABNT; 1987.

28. Grim RE. Clay Mineralogy. New York: McGraw Hill; 1968.

29. Castaldi P, Silvetti M, Santona L, Enzo S and Melis P. XRD, FTIR, and thermal analysis of bauxite ore-processing waste (red mud) exchanged with heavy metals. Clays and Clay Minerals. 2008; 56(4):461-469. http://dx.doi.org/10.1346/ CCMN.2008.0560407

30. Atasoy A. The comparison of the Bayer process wastes on the base of chemical and physical properties. Journal of Thermal Analysis and Calorimetry. 2007; 90:153-158. http://dx.doi. org/10.1007/s10973-005-7671-y

31. Rivas Mercury JM, Cabral AA, Paiva AEM, Angélica RS, Neves RF and Scheller T. Thermal behavior and evolution of the mineral phases of Brazilian red mud. Journal of Thermal Analysis and Calorimetry. 2011; 104:635-643. http://dx.doi. org/10.1007/s10973-010-1039-7

32. Associação Brasileira de Normas Técnicas - ABNT. NBR 152701: Componentes cerâmicos - Parte 1: Blocos cerâmicos para alvenaria de vedação - Terminologia e requisitos. Rio de Janeiro: ABNT; 2005.

33. Associação Brasileira de Normas Técnicas - ABNT. NBR 15310: Componentes cerâmicos - Telhas - Terminologia, requisitos e métodos de ensaio. Rio de Janeiro: ABNT; 2005.

34. Kingery WD, Bowen HK and Uhlmann DR. Introduction to Ceramics. 2nd ed. New York: John Wiley \& Sons; 1995.

35. Associação Brasileira de Normas Técnicas - ABNT. NBR 10004: Resíduos sólidos: classificação. Rio de Janeiro: ABNT; 1987. 